\title{
Persistencia y reescritura del canon picaresco: El azar y viceversa, de Felipe Benítez Reyes
}

\section{Continuity and Rupture with the Canon of the Picaresque Novel: El azar y viceversa, by Felipe Benítez Reyes}

\author{
Carlos Vadillo Buenfil \\ Universidad Autónoma de Campeche \\ cjvadill@uacam.mx \\ ORCID iD: https://orcid.org/0000-0002-2324-0934
}

\section{RESUMEN}

Este artículo analiza las correlaciones y los distanciamientos discursivos y argumentales entre narraciones de la picaresca canónica y la más reciente novela de Felipe Benítez Reyes. En la actualización de la propuesta picaresca, El azar y viceversa (2016) trasluce rasgos de las novelas posmodernas: autoconciencia, ironía, parodia, intertextualidad, «metaficción historiográfica», mestizaje genérico, descreimiento de las utopías, desarraigo espacial del héroe e inestabilidad ontológica; estos elementos nos guían para inscribirla en la neopicaresca de la contemporaneidad. En suma, como planteó Alonso Zamora Vicente sobre las ficciones continuadoras de lo picaril, examinaremos en qué medida El azar y viceversa se sujeta a los relatos truhanescos, y mediante qué maniobras se aparta del canon, lo matiza o le otorga otra dimensión.

Palabras Clave: Felipe Benítez Reyes; El azar y viceversa; novela española posmoderna; narrativa picaresca contemporánea.

\section{ABSTRACT}

This article analyzes the correlations and estrangements -discursive and plot- between the narrative of the most recent novel by Felipe Benitez Reyes and that in the picaresque canon. Upgrading the picaresque proposal, El azar y viceversa (2016) reveals features of postmodern novel: self-consciousness, satire, parody, intertextuality, "historiographical metafiction", genre's blend, disbelief of utopias, hero's space uprooting and, ontological instability; so, these elements inscribe the novel into the neo-picaresque of contemporaneity. In short, as Alonso Zamora Vicente raised on the fictions that continue the picaresque, we will examine to what extent, El azar y viceversa relates to the truhanesque, and by what maneuvers deviates from the canon, nuances it or grants it another dimension.

Key words: Felipe Benitez Reyes; El azar y viceversa; Posmodern Spanish novel; New picaresque fiction. 
El azar y viceversa (2016) supone para Felipe Benítez Reyes (Rota, 1960) el regreso a las narraciones de más de quinientas páginas y la reanudación de tramas picarescas ejercitadas tiempo atrás en El novio del mundo (1998). En ambas novelas los héroes asumen la narración de sus vidas y de sus quehaceres al servicio de múltiples patrones: Walter Arias (El novio del mundo) y Antonio Jesús Escribano Rangel (El azar y viceversa) son ganapanes marcados por las dilatadas desesperanzas y las breves satisfacciones, zamarreados por la inestabilidad; no por nada, el azar preside el título de la novela que nos ocupa, la casualidad que estremece o compensa los destinos, y que, en labios de Marcos de Obregón, «ha sido siempre variable, hecha y acostumbrada a mudanzas de fortuna y ejercitada en ellas toda [su] vida» (Espinel 1973, 29); y, como sentencia el narrador de El azar y viceversa, la suerte es brújula para los que no poseen una brújula.

Las obras aludidas de Benítez Reyes dan la razón a Zamora Vicente, quien observó que los temas picarescos volvían a ser practicados por los más encontrados y dispares autores españoles (1962). Indiscutible es la reflexión del ensayista si se rememoran narraciones breves de Pérez Galdós y «Clarín», novelas de Baroja, Cela, Zunzunegui, Arbó y Umbral; de este siglo son Andanzas y desventuras de un pícaro moderno (2008), de Faro Forteza, y Uno de los vuestros (2016), de Valderrama Donaire. Lo interesante es -volvemos a Zamora- ver qué aportan esas novelas «y qué tienen de sujeción al canon establecido por el Lazarillo y en qué medida se apartan de él, matizándolo, perfeccionándolo o dándole una dimensión distinta» (1962).

Entre la novela de Benítez Reyes y la picaresca se anudan vasos comunicantes: la ilusión de la autobiografía; la eclosión de individuos que representan a «una sociedad donde el parecer significa el ser» (Souiller 1985, 95); la impronta de los ascendientes en la vida del golfante; el apartamiento de la educación formal; los múltiples oficios al servicio de jefes; los desplazamientos; la alternancia de fortunas y adversidades que, incluso, planean sobre los amores fracasados. Por otro lado, entre las mismas obras picarescas fundacionales son comunes las variaciones temáticas y formales (Guillén 1983, 468), por lo que estas no son extrañas entre El azar y viceversa y las ficciones de cínicos, lo que da sentido a la dialéctica continuidad/discontinuidad del género. Por esto, Juan Goytisolo afirma que el escritor debe romper con el canon: no hay obra verdadera sin la idea de novedad. Benítez Reyes cumple con este postulado: presenta mutaciones al modelo picaresco y actualiza su propuesta estética.

El informe de vida de Escribano se estructura en tres apartados denominados tramos; los dos primeros se fragmentan en cuatro subcapítulos y el tercero en seis, pero la originalidad de El azar y viceversa reside en que estos marbetes no se distribuyen convencionalmente a lo largo del relato, sino que al inicio de cada tramo se enlistan los subcapítulos uno tras otro, en la misma página. De este modo, el lector implícito puede asignar cualquiera de los rótulos a la 
secuencia de la historia que crea conveniente, como a veces se le requiere en la narrativa experimental o en los textos metafictivos.

El «Primer tramo» comprende veinte años del héroe en Rota, desde su nacimiento (1958) hasta su marcha a Cádiz (1978); el «Segundo tramo» principia en la última ciudad citada, en los primeros días de octubre de 1978 hasta entrados algunos meses del 79, cuando Escribano se mueve a Sevilla para servir al Tunecino; el «Tercer tramo» se ocupa de su redención -laboral y pecuniaria- y de su descenso por el inesperado estado comatoso de su jefe; la inestabilidad lo desplaza hacia Jerez de la Frontera, última localidad visitada antes de su definitiva vuelta a Rota; este tercer periodo se extiende a inicios de dos mil, cuando interrumpe su peripecia alrededor de los cuarenta y siete años. Los dos primeros tramos corresponden a «la invención de una vida a través de la construcción de una conciencia» (Bonilla 2016, 16), según remarca el autor empírico en una entrevista. El tramo último representa la edad de la conciencia construida, periodo en el que Escribano reconoce con ironía los límites de su doblez: «Incluso los impostores profesionales tenemos un ideario de identidad, un tope de falsía» (Benítez 2016, 442).

\section{El MOdo DisCURSIVo PICARIL DE ANTONIO Escribano}

La verosimilitud de la picaresca deriva de su propia configuración narrativa: el acto confesional de un protagonista concentrado en su existir, a modo de - puntualiza Souiller- una «autobiografía ficticia [...] una narración a posteriori [...] que implica una recomposición y un sentido en el relato» $(1985,42)$. En esta tesitura, el imperativo formal es que el tunante se exprese en primera persona y cuente su relación de vida confeccionada en la madurez, desde una visión subjetiva y retrospectiva. Al dar cuenta de sí, el pícaro lo hace desde un solo punto de vista, por lo que solo se ocupa de comunicar lo que ha desfilado frente a sus ojos; así, lo leído por el receptor es la perspectiva de la realidad que interpreta y altera el personaje narrador (Rey 1989b, 182-183).

Por su miserable y falaz existencia, el yo del pícaro es el de un ser de quien no se hablaría ni escribiría si no lo hiciera él mismo (Molho 1972, 218). De acuerdo con esta lógica, un personaje de baja extracción es capaz de protagonizar una novela, en contra de la preceptiva de la retórica; los individuos menos favorecidos por la fortuna pasan a ocupar el sitio reservado a los nobles (Rey 1990, 86-87). El pícaro no es virtuoso ni idealista; por su origen y sus antisociales comportamientos modela «un anti-héroe, un destructor de los mitos heroicos y épicos, que anuncia una nueva época y una mentalidad nueva $[y]$ se afirma como individuo que tiene conciencia de la legitimidad de su oposición al mundo» (Aguiar 1972, 216). El bribón es «un virtuoso de la apariencia» (Souiller 1985, 90) que se siente poseedor de historia y biografía, por lo que se erige en fabulador para narrarse a sí mismo dentro de un realismo confesio- 
nal (Sobejano 1964). Por tanto, el modo discursivo picaril se configura como un relato autodiegético -como en Estebanillo González-, y la voz advierte al lector que lo que lee no son unas memorias ficticias y que la narración de su vida no es fingida, como la de Alfarache, ni fabulosa como la de Lazarillo, sino una relación verdadera de los prodigios de su vida.

Fiel al canon picaresco, El azar y viceversa sustenta su composición en una realidad bifurcada: un yo narrador que desde la experiencia rememora, cavila y pone a actuar al yo protagonista que fue. Y, a la par del Estebanillo, el autor textual de Benítez Reyes aclara que lo suyo es una relación de hechos auténticos que le ha permitido la autognosis, ya que «no hay cosa que cualquiera de nosotros conozca menos que su identidad más recóndita» (Benítez 2016, 13). A través de la anamnesis, Escribano alcanza el conocimiento de sí mismo, pues desde la madurez puede reconstruir al que ha sido, recuperar su pasado y hasta mudar las valoraciones de antaño gracias a la experiencia; la epanortosis que permite la distancia temporal del personaje la indican los adverbios «hoy»y «entonces», que expresan la doble coordenada del relato; por ejemplo, cuando Antoñito acude a casa de Vidal y se impresiona por la ornamentación: «Hoy, cuando creo estar en disposición de [...] valorar las cosas, sospecho que todo aquello era $[\ldots]$ baratura, pero entonces se me manifestó como un esplendor» (ibíd., 42). En paralelo, el desfase de quien escribe y del que actúa equivale a la categoría hombre maduro versus joven inexperto, como se resalta en Guzmán de Alfarache; ante una estafa se justifica el pícaro: «Era muchacho, no ahondada ni veía más de la superficie» (Alemán 1971, 127).

Sin embargo, Benítez Reyes se aparta de la mayoría de las obras de la tradición picaril al introducir en varias páginas de su texto una voz distinta a la primera persona, como en la Segunda parte de la vida de Lazarillo de Tormes, de Juan de Luna, o en el Marcos de Obregón. El desembrague lingüístico en tercera persona ocurre en el arranque del «Segundo tramo», cuando el enunciador trueca su voz hacia el modo omnisciente, para demostrar sus dotes escriturales. Pero a las veinticinco páginas confiesa hartarse de su experimento y advierte que deja el afán «de escribir de mí mismo como si fuese el personaje de una novela de kiosco» (Benítez 2016, 306), para volver al discurso primigenio. La alternancia de voces sugiere la ruptura con la visión unívoca del pícaro, incapaz del desdoblamiento para contemplarse como si fuese otro; quizás por eso Escribano tiene la convicción de que «si alguien no consigue hablar de sí mismo en tercera persona [por lo menos] una vez en la vida, no pasa de ser un don nadie» (ibíd., 175) ${ }^{1}$. El desembrague de El azar y viceversa apun-

${ }^{1}$ En el Tratado Primero de Lazarillo existe una brevísima mutación de persona gramatical, de la primera a la tercera, para retomarse de inmediato el relato del narrador protagonista: «le dexó caer sobre mi boca, ayudándose, como digo, con todo su poder, de manera que el pobre Lázaro, que de nada de esto se guardaba, antes, como otras veces, estaba descuidado y gozoso, verdaderamente me pareció que el cielo, con todo lo que hay en él, me había caído 
tala la tendencia narrativa posmoderna de socavar la verdad única del relator, la imposibilidad de saber todo desde un solo enfoque o de admitir que existe una única representación estable de la realidad (Madigan 2008, 2).

Otro punto a considerar dentro de la situación comunicativa de la novelesca picaril es la producción de su discurso en función de la recepción interna del mismo. En Lazarillo el narrador personaje satisface a un «Vuestra Merced», receptor inmanente del relato. De forma parecida, en El Buscón el narratario es un «señor», quien funge como destinatario principal y lector explícito representado del discurso de Pablos. El sistema comunicativo entre el emisor y sus diversos receptores, es decir, las continuas apelaciones del autor ficticio al lector explícito concreto en las novelas picariles ${ }^{2}$ también podemos rastrearla en la obra de Benítez Reyes. En su enunciación Escribano se dirige, desde la primera línea de su relato, a un lector ignoto, produciéndose la impresión de oralidad: «No sé si estará usted de acuerdo conmigo» (Benítez 2016, 13), un «usted» que sustituye al «Vuestra Merced», y cuya identidad se develará en las últimas páginas de la novela. Diversos registros adopta la voz de Escribano para dirigirse a la entidad receptora, y no pasa inadvertido cierto aire de familiaridad y complicidad porque sabe bien que trata con un conocido, y que es, además, un profesional de la escritura: «De todas formas, si no tiene usted inconveniente, le hablaré durante un rato, así por encima, de esa masa de niebla que he ido dejando atrás» (ibíd., 14); o bien, por medio de un «le confieso que» (ibíd., 23), o a través de un «como usted comprenderá» (ibíd., 55); o dando por supuesto que el otro es un aventajado colega de escrituras: «La fantasía, en fin, como usted sabe mejor que yo» (ibíd., 211). En otras ocasiones pide la absolución a su lector: «Discúlpeme por no detallarle el trayecto de vuelta, pero hay cosas que, aparte de fáciles de imaginar, son difíciles de relatar» (ibíd., 142); o, «disculpe usted el sermón» (ibíd., 345). Asimismo, en un discurso de alcances metanarrativos, el autor ficticio anticipa al lector explícito que contará más tarde una historia «cuando llegue el momento» (ibíd., 180); que narrará alguna «circunstancia [...] que algo más adelante se verá» (ibíd., 206), o bien, sugerirá un orden de lectura: «Pero antes de entrar de lleno en la historia del Tunecino [...] desplacemos el foco hacia la anécdota del examen» (ibíd., 230). Estos recursos metanarrativos son también practicados en el Lazarillo: «como adelante Vuestra Merced oirá» $(1989,81)$ y, con más recurrencia,

encima» (1989, 73-74). En la Segunda parte del Guzmán de Alfarache surge el rastro de un tú con el que el narrador se dirige al destinatario interno que abandona su papel pasivo o de mero receptor de la conversación para constituirse en agente de la misma al interactuar con el narrador que pretende su adhesión y empatía (Cavillac 2001, 322-325). Para Rico, la inclusión del yo desdoblado en un tú en el relato de Alemán -a veces para recriminarse a sí mismo- es un fenómeno que sugiere la desmembración de una conciencia que se debate entre el instinto o la vida desordenada y la gracia o la espiritualidad (1983, 488).

${ }^{2}$ En Laporte 2011, 367. 
en Alfarache, cuando el galeote se dirige a la conciencia de un «discreto lector», que surge como destinatario interno de su discurso (Bubnova 2006); estrategias discursivas como «de la manera que sabrás adelante»o «como sabrás adelante», son frases que distienden la curiosidad del receptor explícito de la novela de Alemán.

Los registros discursivos del héroe de Benítez Reyes van dirigidos en todo momento a un narratario preciso de la obra, un autor a quien el pícaro conoce por vivir en su ciudad y con el que ha intercambiado impresiones sobre sus ficciones, un escritor que le ha firmado una obra suya después de impartir una charla en la biblioteca de Rota, que suele leer el periódico en un café local y que está casado con la misma joven de la que él estuvo enamorado; en fin, alguien que es depositario de las memorias porque Escribano -ya muerto- se las ha dejado en una notaría, puesto que «algunas de las cosas que cuento aquí tal vez puedan servirle a usted para desarrollarlas en alguno de sus libros futuros» (Benítez 2016, 506) 3 . Dos únicas condiciones pone el autor del informe: cambiar los nombres y los apodos, en caso de hallar algo aprovechable para publicarse, y destruir el libro una vez leído: teme que caiga en manos de sus hijas.

La estrategia del manuscrito resguardado da pie a la fenomenicidad de la novela, por ende, la producción del texto se justifica por una causa no oculta; en este tenor, en El azar y viceversa nadie pide al tunante pergeñar sus recuerdos para explicar una circunstancia -cuestión explícita en el Lazarillo-, sino que, ante la inminencia de la muerte, fueron escritos a toda prisa para su consuelo, para indultar a su pasado. De esta manera, la finitud es la razón que catapulta a Escribano para arrancarse con su relato, y equivale al «caso» de Lazarillo, es decir, la justificación para narrar sus vivencias. Así, «el caso» de las maledicencias sobre Lázaro es la razón para la escritura de sus pillerías, por lo que no solo existe un «caso» en esta autobiografía, sino que esta «depende del caso y a la vez lo justifica» (Rico 1982, 25). En Guzmán de Alfarache el «caso» proviene de la conversión de su autor, lo que genera «el relato retrospectivo, con claras intenciones de ejemplaridad y adoctrinamiento» (Laporte 2011, 288).

La intención manifiesta de Escribano al encomendar su manuscrito no admite dudas: no pretende transmitir enseñanzas, como en la picaresca canónica, sino proporcionar material a un colega ausente y, de paso, plasmar sus huellas de vida y evitar que sus aventuras y desventuras caigan en el olvido. Desde

${ }^{3}$ La asociación entre el escritor anónimo, custodio del manuscrito, y el autor persona suscita la intencionalidad lúdica en El azar y viceversa. Al final de la narración, Escribano (roteño de nacimiento) confiesa al escritor narratario haber leído su libro La naturaleza del paraíso; también comenta que cierta vez este le firmó en la biblioteca del pueblo de ambos un ejemplar de su novela titulada Lo que piensan los monstruos; en el mundo empírico, Felipe Benítez Reyes es también originario de Rota y es autor de dos obras con títulos muy parecidos a los del mundo ficcional: La propiedad del paraíso y El pensamiento de los monstruos, publicados en 1995 y 2002, respectivamente. 
esta operación, Benítez Reyes fractura el molde clásico: Lázaro escribe su epístola-novela por si alguien encuentra en ella algún «deleite» o pueda «sacar della algún fructo» (1989, 61); el escudero Marcos dedica el discurso de su vida a V. Señoría Ilustrísima para dejar «provecho [e] instrucción de la juventud» (Espinel 1973, 3-6); el narrador del Guzmán embarca a su narratario en una galera fictiva para que se convenza «de que los errores e infortunios del protagonista han de redundar, como atriaca o antídoto, en provecho suyo» (Cavillac 2001, 319) .

Guzmán de Alfarache -como enfatiza la crítica-destaca por las digresiones moralizantes y la intercalación de novelitas, apólogos, cuentecillos e historias dentro del discurso del pícaro, artilugios que, observa Moreno Báez, tienen un fondo doctrinal y producen el desbordamiento de la fantasía (1983, 483). Estas prácticas discursivas que ralentizan el ritmo del relato son continuadas por el narrador de El azar y viceversa mediante la inclusión de personajes que orbitan alrededor de sus vivencias o trabajos. La técnica del yo narrativo es la interrupción de la peripecia y del hablar de sí mismo para encajar el relato de un individuo pintoresco o canalla, recurso que dota de viveza la narración, además de que enriquece el mundo circundante al girar la perspectiva hacia los otros, para luego, en otra secuencia, ocuparse el héroe de su persona.

La interpolación de relatos en la narración principal; el empleo del estilo indirecto para narrar lo que a su vez le ha contado al enunciador otro personaje; la incrustación del «nosotros» en vez del «yo» y «los coloquialismos o el uso de las jergas [que contribuyen] al proceso de textualización de la oralidad» (Laporte 2011, 424) son fenómenos narrativos de la serie picaresca canónica, y no es extraño verlos incluidos en El azar y viceversa; ejemplo de relato encajado en la narración central y de la modalidad indirecta de contar es el del dragón onírico de Geva: ella refiere al Fiti y a Escribano las pesadillas que serán reproducidas por este en sus memorias.

Los rastros de oralidad y de jerga son frecuentes en la enunciación de Escribano; los destacamos con cursivas: «A mí, a pesar de ser el más mindundi del tinglado, me tocó coger puerta» (Benítez 2016, 73); «Esperancita [...] se echó un novio quinqui [...] y empezó a meterse caballo» (ibíd., 123); «salí a la calle y rematé el porro [...] para ir abriéndome de par en par el apetito» (ibíd., 140); «iban de tripi y a su bola [...] dando tumbos de chalaíto» (ibíd., 243). Además de sus giros coloquiales, Escribano incorpora registros provenientes de otros personajes, intervenciones que, como observa Laporte sobre el narrador de la picaresca, respetan la mímesis conversacional y dan un efecto de comicidad y

${ }^{4}$ La misma intención didascálica se advierte en La familia de Pascual Duarte (1942), de Cela: Pascual, lindante con la figura del pícaro, envía sus memorias a un ilustre, pues teme destruirlas y privar a los demás de aprender lo que él no supo ya demasiado tarde, aunque también pretende engendrar la conmiseración de su lector ante el determinismo de su nacimiento y la mala fortuna que tanto se ensañó con él. 
sátira a la historia relatada $(2011,429)$. Para ilustrar lo anterior anotamos varios repertorios lingüísticos de El azar y viceversa: «Tú quién sus creéis que soy yo pa estas porquerías? ¿Una comebichos?»(Benítez 2016, 67), dice una novia gitana al bribonzuelo; «Ezo ez muy egoízta por tu parte» (ibíd., 193); «¿Tú erez un loco o qué? [...] Tú lo que ere e un hijoputa egoízta [...] No me vengaz tú con cuento» (ibíd., 241), son las reproducciones del ceceo de una condiscípula; también se transcribe el lenguaje repetitivo y las construcciones sintácticas enrevesadas de un ebrio: «A mí, escucha, canijo, es que eso es lo que yo digo siempre, ¿no? El saber estar, lo ¿captas, canijo?» (ibíd., 303-304).

En resumen, las improntas orales caracterizan a la picaresca española: las transcripciones directas de escenas dialogadas entre los personajes, la presencia de verbos que implican un acto del habla en las intervenciones del narradorconversador, el uso de refranes, el añadido de anécdotas ajenas al relato principal, la recurrencia a la analepsis que interrumpe el relato, el uso de palabras y frases coloquiales, son todos elementos que originan dicho efecto oral (Laporte 2011, 423). De entre estos elementos señalados, la reproducción literal de los refranes es el menos concurrido en El azar y viceversa, pues son sustituidos por reflexiones enhebradas por el narrador textual: «de sobra está pregonado que la vagancia es un hechizo que se vuelve permanente si no se le encuentra a tiempo un antídoto» (Benítez 2016, 326); «Pero está visto que no hay paraíso sin serpiente» (ibíd., 328); o bien, el refrán es reemplazado por una sentencia: «comprendí que la felicidad es algo muy simple: basta con inventarla» (ibíd., 422).

Por otra parte, las prosopografías mordaces de Escribano son otro rasgo de estilo a destacarse, y se relacionan con los fantoches que en El Buscón delinea su autor, aspecto constructivo que asemeja una «organización guiñolesca» (Lázaro Carreter 1983, 495). Escribano compara al gordo empresario Rivas con un «elefante marino con guayabera» (Benítez 2016, 112); a Jacinto el Séneca, dueño de bar, lo describe con «patillas de hachita, porte de bailarín de alguna danza del fuego y una palidez aceitunada de Drácula gitano» (ibíd., 180), y a Romero, el diputado, lo iguala con un «forzudo de circo en miniatura [...] como quien lleva un disfraz, o como poco un uniforme de faena» (ibíd., 414). Tampoco escapa el espiritual Ripaldi: «Vestía al aire hindú, con un blusón amarillo con ribetes entredorados, y el pecho se lo adornaba un medallón de traza simbólica, con apariencia de cornamenta mística» (ibíd., 427). La agresión y el castigo hacia los otros se expresa en el mundo picaresco a través de la burla y la celebración de la risa, y el pícaro no duda en echar mano de ellas para degradar a los que se encuentra en el camino (Zea 2016, 127-128). Escribano despoja de solemnidad a sus líneas que se alzan en contra de su inminente fin, y construye una «verdadera épica bufa [o] rueda de aventuras extravagantes» 5 .

5 En Ana Rodríguez Fischer (2016). «Ronda de pícaros», reseña, El País, Babelia, 18 de mayo, p. 7. 
Zamora Vicente razona que el personaje pícaro -a partir de Guzmán de Alfarache-realiza «una valoración de la vida y una preocupación por su fluctuar» (1962); en este tenor, la novela de Benítez Reyes concierta con la picaril, aunque las intervenciones de Escribano son lacónicas y sus juicios consumen pocas líneas, más enfocadas a la opinión y a la autoconcienciación que al adoctrinamiento y al sermón, incluso se mofa del tono pudoroso de la moral, como veremos más abajo. Esta conciencia de sí lo conduce a diagnosticarse en ciertos tramos de su discurrir; él puede engatusar a otros pero no es capaz del autoengaño: a los veinte se desengancha del hachís que lo había «convertido [...] en una especie de titiritero que no paraba de lanzar al aire unas ideas de colores para procurar alegrarse un poco su vida inútil» (Benítez 2016, 170).

La reflexión sobre sí mismo y su entorno, las lecturas cultas y las intentonas literarias configuran la etopeya de un sui géneris pícaro que se vuelca a la escritura. Y, en contra de casi toda la estirpe picaril, Escribano gusta de los libros y de las lecturas filosóficas y fantásticas, además de su afición por los tebeos de superhéroes. En este sentido, su curiosidad intelectual se asemeja a la figura de Marcos de Obregón, quien confiesa que los libros son amigos que hacen libre a quien los quiere bien: « $i \mathrm{Oh}$ libros, consuelo de mi alma, alivio de mis trabajos, en vuestra santa doctrina me encomiendo!» (Espinel 1973, 43). Escribano merodea por las librerías, lee gustoso y roba horas al sueño. Ante la biblioteca de Escapachini se dice que él también tendrá una «para dedicarme al estudio y a la meditación y no irme del mundo sin enterarme [...] de su misterio infinito» (Benítez 2016, 143). Por eso, se camela el Tesoro de la lengua castellana o española, de Covarrubias, y se empeña en el aprendizaje de palabras.

El pícaro supone - puntualiza Marcos de Obregón- que su discurso «lleva mucha sustancia, que aquí no se escriben hazañas de príncipes y generales valerosos, sino la vida de un pobre escudero que ha de pasar por estas cosas y por otras semejantes» (Espinel 1973, 96). De esta guisa, Escribano es como los bribones canónicos que al materializar su acto comunicativo arreglan un entretenido libro para trascenderse a sí mismos; su vida apicarada es digna de contarse, pero también, al narrar la de los otros, Escribano ejerce como cronista y compone «la mitología municipal [esa] epopeya sin gloria ni heroísmo que escribimos entre todos en el aire» (Benítez 2016, 117). Al ejercicio locutivo del barbián y a la censura que vierte sobre su conducta y las de los demás se acomoda la estimación de Sobejano sobre la picaresca: la «locuacidad crítica» $(1972,467)$. Caracterización a la que no es ajena la obra del autor roteño.

EL APICARAMIENTO DEL SER

La apariencia y la falsedad desavenidas con lo verdadero y lo real dan sustancia a la prosa picaresca. Un descubrimiento del incauto bribonzuelo es que el mundo no es lo que parece ser; aprendizaje que irá fortaleciéndose en 
sus continuas metamorfosis. La pregunta que permea el relato picaresco es si es posible la unidad del ser detrás de las variadas caretas del parecer (Souiller 1985, 64-65).

El azar y viceversa restaura la premisa del ser y el parecer; su narración inicia -en un alarde posmoderno- cuestionando la identidad del yo y subrayando los desdoblamientos del ser: «creo que todos llevamos una triple vida, sustentada en tres pilares: lo que creemos ser, lo que quisiéramos ser y lo que en verdad somos» (Benítez 2016, 13). La estabilidad de la conciencia depende del equilibrio de la conjugación de esta tríada -cavila la voz narrativa-, y reconoce que «no hay cosa que conozca uno mejor que su vida aparente y que su vida imposible» (ibíd., 13); por tanto, buena parte de la existencia se sustenta en las distorsiones del azogue. Los enmascaramientos se fortalecen al afirmar el relator que nos narramos «a través de meras anécdotas [y] una anécdota no es más que un entresueño disfrazado de realidad» (ibíd., 13).

Los sujetos que habitan el mundo "se vuelven del revés, de tal manera que más tarde o más temprano se revelan lo contrario de lo que parecen, de lo que fueron o de lo que son» (Molho 1972, 71). El aprendizaje de estas inversiones lo adquiere el adolescente Antoñito de sus sucesivos trabajos; como ayudante de Gavilla se percata de las destrezas retratistas de su jefe al trocar a los palurdos en actores de cine: «sabía convertir a sus modelos [en] impostores» (Benítez 2016, 46). Al ascender de pinche de cocina a ayudante de camarero recibe dos uniformes que se le figuran un disfraz; su madre exclama: «Pareces el capitán de un trasatlántico» (ibíd., 49). Como camarero es testigo de los militares que acuden con prostitutas del pueblo, a las que disfrazan de prometidas, ya que también en el amor «circulan muchos billetes falsos» (ibíd., 150), como refiere el yo ficticio. La realidad es, afirma la anticuaria Geva, como el actuar de su gremio: «En lo nuestro hay más falsedad que en un cónclave de obispos [...] Más falsificaciones que en un corazón» (ibíd., 199). No por nada, el conocimiento de la realidad obliga a Escribano a decirse en el «Tercer tramo» que ha «llegado a la conclusión empírica de que todo es extraño, en especial lo que no lo parece» (ibíd., 418). Otro caso de simulación de identidades lo representa Charli, el enano que se pinta una boca articulada para intercambiar roles: él en el papel de monigote, el muñeco en función de ventrílocuo.

El roce de las apariencias envuelve también las designaciones que adoptan los pícaros, según sus conveniencias. El héroe de Alemán altera sus nombres: al salir al mundo afirma que para no hacer valer el apellido de su padre se puso Guzmán, como su madre, y Alfarache, por la heredad donde nace, pero en Génova responde a Don Juan de Guzmán. Asimismo, para cortejar a una dama Pablillos se trueca en Don Felipe Tristán. Al no parecerle sonoro, un camarada de Pablos se cambia el nombre de Mata al de Matorral. En El azar y viceversa el yo fabulador tampoco escapa a las mutaciones nominales, aunque a Escribano se las imponen los otros: de niño es Antoñito; de joven es bautizado como «Rányer» por el Fiti, quien afirma que «un alias es la expansión falsa del yo, 
que es otra falsedad» (Benítez 2016, 156), por eso intercambian sus apodos, de modo que «los dos éramos uno y ese uno era, al fin y al cabo, nadie» (ibíd., 190); en Sevilla es designado como Padilla, por haber suplido a un obrero de ese apellido, pero después es llamado Jesús, su segundo nombre de pila; de vuelta a Rota, su novia y futura mujer se empeña en llamarlo Toni, mención que siempre detestó.

En la era de la metamorfosis la esencia del yo de la posmodernidad se desvanece junto con el nombre mismo, transformándose en algo mutable e inestable (Lozano 2007, 168). Así, los motes inclinan al engaño, como es el caso del bar «Séneca» donde se coordinan trafiques; no es de extrañar que el dueño tenga como apodo el nombre del bar, aunque viva más apegado a lo material que a la templanza y al senequismo. ¿Dónde comienza la verdad y dónde termina la mentira? Es un cuestionamiento que vertebra la narración de toda aventura picaresca, ya de la clásica, bien de El azar y viceversa. No por nada lo esgrime Guzmanillo: «no hay cosa segura ni estado que permanezca [...] todo es fingido y vano» (Alemán 1971, 45); y lo secunda Escribano al argüir que «la mar se parece mucho a la vida, por lo que ambas tienen de prodigios inestables» (Benítez 2016, 15).

Los equívocos se cuelan también en las genealogías de los fulleros. Dar cuenta de los orígenes es parte de la picaresca, por consiguiente, los ascendientes indecorosos afloran en las iniciales páginas relatadas por Lázaro, don Pablos y Guzmán; estos antihéroes cuentan con ironía sobre sus padres y sus turbias famas, estigmas que prueban el determinismo que los condujo por malos senderos. En El Buscón la aversión sanguínea de don Pablos se extiende hacia su tío, un majadero de oficio verdugo. Auto zaherirse y exhibir la propia indignidad para reírse de sí mismo, da al pícaro permiso para burlarse de los otros (Roncero 2010, 70). Por el contrario, Escribano no proviene de una vergonzosa cuna; sus orígenes son modestos pero decorosos. Su padre era un contable, sin mayores pretensiones, que falleció de leucemia. Los recuerdos por ese hombre son amables y nostálgicos, sobre todo por sus enseñanzas sobre la mar. La madre de Escribano fue propietaria de una mercería y, en su viudez, de una pescadería heredada; lo censurable en ella son sus continuos afeites de mujer fatal para ligar con mílites extranjeros. Pero más que una condena, los párrafos que describen las ligerezas maternas trazan una justificación por la carencia de afectos masculinos. En El azar y viceversa el motivo de la ignominia familiar de Escribano deriva - como en Lazarillo- de su padrastro, que además es el hermano mayor de su progenitor, quien viudo $y$, en connivencia con sus abuelos paternos, contrae nupcias con su madre, también viuda, para lavarle las manchas de su pasado promiscuo. La honra y la pureza de los siglos XVI y XVII se trasvasan a mediados del XX en el concepto de decencia perfilado por los roteños, que toleraban las relaciones de las locales con los americanos si acababan en boda, «pero que era la mismísima peste bubónica para las que lo tenían como pasatiempo» (Benítez 2016, 66). 
El suplantador del padre de Antonio es un individuo autoritario, zalamero con los poderosos, juerguista y maltratador de esposa e hijastro-sobrino; para no escribir su nombre el narrador lo apoda Fantomas, acaso por recordarle al elegante ladrón de tebeo. Al prodigarle a su hijastro el aprendizaje del dolor, el tío-padrastro halla su paralelismo con el verdugo tío de Pablos. En cuanto puede, Antonio exhibe las apariencias de su padrastro, sus rebajamientos, sus petulancias, como la de hacerse pasar por gran señor y acaudalado al comprar una casa en el centro de Rota. Por eso, Escribano se burla de sus pretensiones burguesas, ya que el sentido de la honra es en todo momento ridiculizado por los pícaros (Souiller 1985, 22). La hipocresía circunda a su breve familia, que es, diagnostica, «una representación teatral fallida: todos los actores se ven obligados a ponerse un disfraz y a asumir un papel, pero nadie sabe actuar» (Benítez 2016, 86).

En su papel de hijo comprensivo, Antonio intenta entender a Herminia, su madre, en esa manía de teñirse el pelo de color oro y disfrazarse de adolescente para liarse con militares de la base americana instalada, a inicios de los cincuenta, en Rota. Su sospecha es que ella nunca encontró al príncipe azul, como las ascendientes de Guzmán, proclives también a los amores enrevesados: «Si mi madre enredó a dos, mi abuela a dos docenas» (Alemán 1971, 26). La frontera entre lo fingido y lo verdadero también es traspasada por Herminia, que gusta de entretejer, por sus dos apellidos, las quimeras de un linaje aristócrata, como solían exponer la abuela de Guzmán y la madre de Estebanillo, quienes proclamaban ascendencias nobles. Pero los aires de grandeza de Herminia chocan con su oficio de vendedora de pescados, tan adornada de sortijas de oro «que más parecía una emperatriz que jugaba a ser pescadera en una mascarada en los jardines de Versalles que una pescadera que jugaba a su modo a fingirse emperatriz» (Benítez 2016, 20). De esta guisa, El azar y viceversa dialoga con la picaresca, pues «con el Guzmán de Alfarache entra en el género [...] el tema de la burla de la nobleza y de la manía nobiliaria de los españoles tan caro a los bufones» (Roncero 2010, 120).

El entramado picaresco apuesta por el verdadero aprendizaje de la calle. Del aula desertan Lazarillo y don Pablos; a Estebanillo lo echan del colegio por trapacero y, Guzmanillo, algo mayor, se enamora y desatiende su carrera de teología para casarse por vez segunda. Fiel a la usanza de desenvolverse en el espacio público, Antoñito -huérfano a los doce, la misma edad en la que Guzmán queda en el desabrigo paterno- es reclutado por su madre para entregar pescado a domicilio; a los trece años es obligado a abandonar los estudios, pero -resaltamos la discontinuidad de El azar y viceversa- es una decisión en contra de su voluntad, bajo el pretexto materno de la bancarrota. Su primer empleo es el de repartidor, y su ascendiente es su inicial ama. A ella roba su primera moneda y descubre el poder del dinero que todo compra; su iniciática experiencia del hurto fácil y azaroso le revela la malicia y la codicia-como a los pícaros de la tradición-, la «visión de la sociedad donde el dinero es rey» 
(Souiller 1985, 78); por este motivo, el adolescente Antoñito no duda en sustraer dólares de las carteras de los amantes de su madre. Escribano se aproxima a Guzmán de Alfarache - «marcado desde su nacimiento por la suciedad del dinero» (Molho 1972, 67)-, y, desde el primer día como estudiante simulado en Cádiz el «Rányer» no descarta la rapacería: «calculé que podría tratarse de una vivienda digna de ser tenida en cuenta para darle un tiento si la cosa de las finanzas se me ponía al rojo vivo» (Benítez 2016, 180-181).

La temprana experiencia del tránsito por los caminos adiestra al pícaro en dos asignaturas: la dureza del mundo circundante y la posesión de la libertad individual. El sacudimiento de la conciencia de Escribano -como el de los taimados de la ficción- va de la mano de la comprobación de la aspereza mundana. La libertad es una legítima defensa, un tesoro que protege el indefenso contra quien pretenda sojuzgarla, caso de Fantomas cuando obliga al hijastro a aportar su sueldo. Mediante el desprecio y la ignorancia de los trabajos que le busca su padrastro, Escribano protesta contra el que impide su albedrío, pues no le pasa inadvertido que los despojos de sus ingresos son para pagar deudas mobiliarias.

Un distintivo de la picaresca -por lo menos en Lazarillo, en Guzmán y en Marcos de Obregón- es el servicio a muchos amos ${ }^{6}$. En Lazarillo, por ejemplo, el narrador menciona por lo menos a diez. En El azar y viceversa se cumple este punto, y desde la adolescencia el héroe inicia la ronda de oficios al servicio de un jefe; unos le duran días, semanas o meses, ya por enfermedad o muerte del dueño, por cierre del negocio o porque lo echan por fullero. De los trece a los veinte años despacha en un bazar, es asistente de un yesero, de un zapatero y de un fotógrafo de estudio; es camarero en un restaurante y en un bar sórdido; subalterno en un taller mecánico, acomodador en un concierto y en un par de sesiones de box; empleado en una tienda, lazarillo de conferenciante ciego, mecanógrafo de dramaturgo, repartidor de correspondencia, guarda nocturno y vendedor ambulante de helados. El oficio que más se apega a la picaresca canónica es cuando acompaña a un semiciego conferencista a un viaje de ida y vuelta, de Rota a Alcalá de Henares (su primera salida del terruño); el anciano disertante escamotea al joven la comida durante el trayecto en tren y en la breve estancia. Después del coloquio, la asociación anfitriona ofrece un refrigerio en honor del intelectual, y el pícaro hambreado se zampa todos los canapés que puede, pero para su sorpresa descubre que los pocos asistentes no le van a la zaga.

En paralelo a las labores enumeradas, o en los largos intervalos de desocupación, el existir de los primeros veinte años de Escribano se escora hacia el aprendizaje del inglés y de la mecanografía; sus aficiones son los amores mís-

\footnotetext{
${ }^{6}$ Este rasgo estructurador desaparece con frecuencia en las novelas picariles de protagonista femenina.
} 
ticos y fugaces, los tebeos, ciertos libros, la música psicodélica, el billar y el ping-pong; sus vicios son el alcohol, los ácidos y los canutos.

En el Primer tramo del héroe sus ingresos resultan de los birlos en la pescadería, de los dólares de los novios de Herminia, de los desvalijamientos de viviendas de soldados guiris, de las comisiones por las ventas de estraperlo y de los porcentajes de los trapicheos del personal del restaurante norteamericano; esta última situación lo lleva a expresar que en «aquella comunidad del latrocinio, [...] de inmediato me sentí a mis anchas» (Benítez 2016, 54), bellaquería que recuerda a Pablicos, cuando se asocia con la despensera de don Diego para apropiarse de los comestibles que sisaban.

El primer viaje a Cádiz de Escribano es a los veinte años, y es el mejor pretexto para alejarse de su familia y obtener conocimientos humanísticos: ha sido contratado por un joven burgués, el Fiti, para suplirlo como estudiante de letras, a cambio de techo, comida y cien pesetas diarias. Pero sus apuros económicos no cesan. Sin dinero extra, como le había prometido el Fiti, comercia con muebles que recoge en los portales; durante dos meses es lazarillo de un comerciante, que acaba suicidándose; es pintor de casa y mecanógrafo de un coleccionista de objetos raros $\mathrm{y}$, de nuevo, «en parte por atavismo y en parte por necesidad» (Benítez 2016, 259), comete raterías en los comercios; es estraperlista de tabaco y negocia el hachís suministrado por Cupido, ilícitos que aproximan al héroe a Estebanillo, vendedor de jaboncillos falsos y polvos.

El trastorno mental del Fiti ocasiona el abandono de los estudios y la miseria de Escribano, proyectado al tercer y último tramo: Sevilla, Jerez de la Frontera y Rota. Los últimos momentos de su vida en Cádiz - que podríamos intitular «Las cosas y las gentes», como sugiere el último subcapítulo del «Segundo tramo»-, acercan la infeliz vida estudiantil de Escribano a la del educando Marcos, que se queja de que las carencias «tienen muchos y grandes ingenios acobardados, arrinconados, y aun distraídos por la privación de sus esperanzas mal logradas» (Espinel 1973, 56). A la resurrección de sus esperanzas contribuye el Tunecino, que contrata al desesperado Escribano para laborar en Sevilla; el nuevo amo es un empoderado comerciante que se erige como su protector, además de padrino de su efímero primer matrimonio. Allí el pícaro se siente reconciliado con la vida, y en su bonanza deja atrás las gandulerías y pasa a ser el empleado de confianza de aquel rey de las ventas, hasta que la enfermedad y el coma del jefe derrumban su bienestar. El Tunecino cumplió el papel de último amo del protagonista. En los últimos espacios de la novela, más que jefes encuentra protectores: uno por darle ingresos (Romero), otros por regalarle techo y comida (Ripaldi, Charli, el tabernero Tiresias).

La casualidad, las ocupaciones y los desplazamientos que experimentan los pícaros los vinculan con un abanico de individuos estrafalarios, sinvergüenzas o torvos. El azar y viceversa tampoco se aparta de estos equívocos del ser y el parecer. $\mathrm{Su}$ socio Kwan encandila a las muchachas, pero Escribano descubre una encubierta masculinidad. El Fiti es sinónimo de la doblez: un cautivador 
de mujeres atravesado por la inmadurez, la ofuscación y la bisexualidad, «como si todo él fuese a la vez una verdad y una mentira, un dato incuestionable y un delirio en caída libre» (Benítez 2016, 260). Caricato del saber es Escapachini, explotador y canalla es el coleccionista de arte Miranda, como embustero es el poetastro Veragua; carroñero es el diputado, como entrañable suplantador de identidades es Charli; simulado anarquista es Cupido, y aparente empleada de una agencia de viajes es Inmaculada, que en realidad es socia del establecimiento. Otras veces flotan interpretaciones encontradas y no es posible establecer la veracidad, como sucede con el Salitre y su probable extorsión de posguerra a García de Quirós, o con el contable Sanchís y las causas de su libre reclusión, o las versiones sobre los negocios del Tunecino.

Esta doble cara de las personas encuentra su equivalencia con la etopeya del pícaro. A una conducta establecida como correcta por la colectividad opone la suya, la auténtica -según su código- para descalificarla. La justificación de la retorcida moral practicada por los bellacos es frecuente en sus narraciones, excusando su propia inmoralidad al aducir que la culpa de sus trapacerías es de la misma sociedad a la que expolian. Escribano es orillado a las prácticas picarescas por su padrastro, y a propósito abandona o no acepta empleos que le granjea su ascendiente; en otra ocasión coge el trabajo de camarero en un bar infame, para aportar - con total marrullería- una miseria a la hipoteca de la casa. Por eso también se marcha de Rota, por no padecer más las humillaciones de Fantomas, y se lanza a la aventura de reemplazar al Fiti. A la par, respalda los atracos a los chalets de los soldados norteamericanos por creerse un vengador ideológico, «un saboteador de los invasores» (Benítez 2016, 81), como decían los radicales del Hades, y para no pasar hambres no duda en la redacción chapucera de un texto pagado por un estudiante -la picaresca académica-. Asimismo, por caer bien a una atrayente poeta no le importa el fraude literario y presenta en una tertulia un menjurje poético que es descubierto gracias a su «sino irredimible de impostor» (ibíd., 245). Escribano es un farsante obligado por las adversidades, pero también por reivindicarse se confiesa enemigo de la holgazanería y la vagancia, y es capaz de ser honrado, como cuando es empleado del Tunecino.

Los movimientos de estado que ocasionan la fortuna son leitmotiv en las historias picariles, al grado de que Benítez Reyes lo consigna en el título de su obra. No en vano las circunstancias azarosas han conducido al narrador a tildarse como «el Doncel Expuesto al Destino Aleatorio» (Benítez 2016, 348), y lo persuaden de que «las vicisitudes de la fortuna no perdonan a nadie ni a nada» (ibíd., 404), deliberación paralela a la exhibida por Guzmán: «Cuanto hay hoy en el mundo, todo está sujeto a mudanzas y lleno dellas» (Alemán 1971, 349). La prueba es el denigrante retorno del héroe a Rota, porque «la vida [...] a veces se dedica [...] a dar cabriolas de saltimbanqui» (Benítez 2016, 349). La fortuna sitúa a Antonio en un mundo al revés, como ubicó también a Lázaro en sus andanzas, e igualmente a ella deben los pícaros la mayoría de 
sus desgracias (Souiller 1985, 42). Rota participa de la duplicidad, y es punto de partida y retorno de Escribano $^{7}$, la marca de su fracaso material, como lo fue Sevilla para la existencia de Guzmán (ibíd., 48).

Las pruebas rituales del pícaro son la cárcel y el amor malogrado (ibíd.: 85). Salvo su detención y encierro de un día en una caballeriza, escarmiento que le da el concejal Fantomas a través de la policía secreta, Escribano nunca pisa la cárcel. Cuando el Séneca, para lavarle las sospechas del robo a la casa de Miranda, le da a elegir entre la cárcel o el hospital, Escribano elige, a regañadientes, la segunda opción. De este modo, la reclusión por historial policiaco es prueba superada en nuestra novela.

El segundo rito en la narración de Benítez es «El amor y su cautiverio», como reza el segundo subtítulo del «Tercer tramo». De acuerdo con esta máxima, conviene contraponer la novela del roteño con la prosa tradicional del malandrín masculino, en la que «la sexualidad de los pícaros [...] es permanentemente omitida» (Montauban 2003, 13), así como el tema de la paternidad y los hijos; por el contrario, en El azar y viceversa los encuentros eróticos son explícitos. El primer contacto erótico del pelirrojo golfillo es la mujer de Vidal: por orden suya la peina, unta crema y le sube la cremallera de la espalda. A esta experiencia se suceden amores idealizados con un par de adolescentes, hasta dar con Macarena, que lo masturba en el bosque. Escribano no se considera bien parecido, reconoce su timidez «incluso con las mujeres de los clubes de carretera y manta» (Benítez 2016, 473), y es incapaz de una relación cabal: los encuentros con las mujeres son pasajeros, de una breve temporada, como con Lali, la comunista partidaria del amor libre, o con la mística Mabel; a veces, obtiene sus placeres eróticos previo pago o tiene sexo gratis pero mecánico con las contemplativas del cortijo; $y$, cuando parece consolidarse el vínculo mediante un matrimonio, es porque se ve forzado a casarse por el embarazo de María, un casorio tormentoso que deviene en aborto y divorcio. A más de cuatro años de haber vuelto a Rota, tampoco consolida una unión estable: «había tenido cuatro o cinco novias de las que prefiero no escribir ni el nombre, y se supone que debía estar escarmentado con respecto al viejo arte de amar» (ibíd., 472).

En la prosa picaresca el amor es caricaturizado y castigado con la risa, además de que «es reemplazado por una sorda agresión entre ambos sexos, y las relaciones humanas se reducen a un medio para medrar socialmente» (Zea 2016, 133-134). El amor que transmuta a Escribano procede de la mano de

${ }^{7}$ Rota es un espacio que también participa de los espejismos del «parecer»; así lo recuerda Benítez Reyes: «Nací en un lugar que en los años 70 tenía Chevrolets, motos chopper, carteles en inglés, restaurantes chinos, lavanderías... Algo que sólo estaba en las películas y en mi pueblo del sur. El desembarco de soldados norteamericanos era un espectáculo que llamaba a la noche, a las putas, al trasnoche y al dinero. Si trasladas una cultura extranjera a un pueblecito pesquero y campero en los años 60 el resultado es alucinante. Y así lo viví yo» Lucas 2016, El mundo http://www.elmundo.es/cultura/2016/05/18/573b604c46163f8d758b45b5.html 
Inma, con la que se casa a los treinta años. Se confiesa feliz y sereno de espíritu, con el temor de que «la sonrisa de la fortuna [de pronto pueda] transformarse en la de la hiena» (Benítez 2016, 481). Con la llegada del amor auténtico dictamina que su vida no ha sido «esencialmente mala, eso no, aunque sí inestable» (ibíd., 483), y su vida matrimonial se estabiliza con las niñas que procrea. Conforme a esta responsabilidad, Escribano se excluye de la vida apicarada y, del lado de Inma -desahogada en lo económico-, se reintegra a la vida social; por «la rareza intrínseca del mecanismo acrobático de la vida» (ibíd., 93) hasta conoce y departe en paz con un hijo suyo mayor de edad, cuya existencia nunca le informó Mabel; entonces, la novela de Benítez se parece más a la edición francesa del Buscón de 1633, donde el traductor da un giro nuevo al introducir el enamoramiento de Pablos de la hija de un mercader rico, el casorio y una vida estable y próspera (Souiller 1985, 112).

El fario de Escribano rompe con el determinismo social: reconoce que «iba para víctima colateral de la mecánica insensata del mundo» (Benítez 2016, 14), pero, contrario a los finales de las narraciones picariles, su caso es el de «una persona venturosa y hasta diría que tirando a feliz» (ibíd., 14). Pero cuando más disfruta del existir apacible y administra su propio quiosco de lotería, cuando se cree como Lázaro en la «prosperidad y en la cumbre de toda buena fortuna» $(1989,141)$, la muerte tronza su futuro.

\section{PICARISMO Y POSMODERNIDAD}

Sin dejar de reconocer la narrativa experimental cultivada a partir de los años sesenta, Holloway observa que la novela española posmoderna cobra vigencia a partir de 1975, año que marcó una nueva etapa histórica para España: la transición política $(1999,39)$. En juicio parecido, Oleza sustenta que a partir de los ochenta buena parte de las novelas españolas se fundamentan en la representación de la realidad desde el punto de vista, la situación y la voz de un personaje determinado, e intentan renovadas exploraciones en torno de un abierto y plural postmoderno realismo (1993). De esta suerte, la novela posmoderna española «no solo tematiza nuestro mundo posmoderno, sino que la forma de hacerlo nos lleva directamente a él, uniendo forma, fondo e interpretación» (Lozano 2006, 223). Los teóricos de la tendencia posmoderna han cimentado sus estudios desde diversos saberes; los que más fundamentan nuestro análisis de El azar y vicever$s a$ provienen de lo literario, lo histórico y lo filosófico.

Orejas sostiene la inclusión de la metaficción en la narrativa española contemporánea, además del intimismo, la autorreflexión y el mundo interior frente a la realidad social $(2003,268)$; por su parte, Holloway insiste en que las novelas publicadas en España a partir del periodo apuntado revelan coincidencias: predominio de la ironía, la parodia, la intertextualidad y la heterogeneidad genérica $(1999,33)$; el carácter metanarrativo y la reinstauración del contexto 
histórico (eliminado por la novela modernista) son cualidades destacadas por Linda Hutcheon al analizar el posmodernismo narrativo occidental (Barbancho 2011, 98) surgido a partir de la segunda mitad del XX. En consecuencia, el concepto de destemporalización (Navajas) nos será útil al momento de examinar el trasfondo histórico de la novela de Benítez Reyes. En cuanto a lo filosófico, acentuamos el descreimiento de las utopías que dominan la modernidad (Holloway 1999, 38), y la falta de certezas y de verdades únicas que conducen al relativismo ontológico y epistemológico (ibíd., 33).

Ni duda cabe de que El azar y viceversa evidencia rasgos de autoconsciencia. La voz posee la convicción de que su escritura no pertenece a lo novelesco, sino al ámbito autobiográfico. El autor es consciente de que produce un discurso confesional y lo pone de manifiesto a su primer lector, al heredero de su manuscrito. En El azar y viceversa no es una dominante la reflexión sobre el acto de la escritura o el proceso de creación, pero sus rastros se perciben en las dificultades reveladas por el autor ficticio:

Lo curioso es que la historia de tu vida se te manifiesta entonces como una secuencia de planos superpuestos en la que se enmarañan los hechos y las fechas, los nombres y la gente: todo se vuelve inconexo y trivial, surreal y desconcertado $\mathrm{y}$, en el preciso instante en que cedes a la imprudencia de poner por escrito tus recuerdos, te sientes como si acabases de abrir la caja de un puzzle de cinco mil piezas. Al menos eso fue lo que me pasó cuando emprendí esta autobiografía (Benítez 2016, 502).

Otra huella de la autoconciencia se da al puntear Escribano el cuerpo de Inma. Al percatarse de su registro indecoroso pide discreción a su narratario; Escribano tiene conocimiento de que habla más de la cuenta «porque no creo que Inma aprobara la divulgación de estas intimidades, de modo que le ruego que las considere información confidencial» (ibíd., 479). Secuencia también de alcances metafictivos es la alusión de Escribano a la dudosa calidad de su texto, como para atenuar el rigor crítico de su receptor: «Sé de sobra que esto tiene menos valor literario que testimonial [...] no soy ni mucho menos un escritor, lo que se dice un verdadero escritor» (ibíd., 505).

Más casos de autoconciencia irrumpen cuando Escribano advierte a su lector que le contará, «así por encima» (ibíd., 226) la historia del Tunecino, que a su vez el Séneca se las contó al Fiti y a él, o cuando reproduce el breve relato fantástico que Geva cuenta a los dos amigos. En este último caso, el narrador no ignora que está adjuntando una tesela en el mosaico que es la relación de su vida, y hasta le concede un título para distinguirla, «como a esas historias que ocurren dentro de otra historia» (ibíd., 236).

Por el tono de su obra narrativa, poética y ensayística, Benítez Reyes ha sido considerado, junto a autores coetáneos suyos, un escritor mantenedor del 
estilema humorístico posmoderno en España ${ }^{8}$. El azar y viceversa no es excepción, y como novela posmoderna es paródica en grado extremo. No olvidamos remarcar que la ironía y la parodia son dos procedimientos retóricos a los que acude el posmodernismo para deconstruir el pasado literario: lo inserta y a la vez lo subvierte en una nueva recreación (Lozano 2007, 143). Sutil ironía y paradoja es que el emborronador de su propia vida y de otras historias fundidas en su discurso se apellide Escribano, al igual que el amanuense que copiaba folios en la antigüedad, y que a veces surge en la trama picaresca. El paralelismo con la novela canónica consiste en que si un sujeto proveniente de un estrato inferior es capaz de redondear una narración, un individuo de apellido Escribano, más o menos culto, también pueda redactar una novela. Similar a la de su creador empírico, la pluma de Escribano destila humor y parodia al contar escenas de una película pornográfica en dibujos animados, cuyas figuras provienen del medioevo (juglar-princesa). No extraña que Escribano parodie el estilo de la literatura contemplativa al asistir a Ripaldi, guía de la secta sij, para escribir un volumen, configurándose una picaresca mística y una sabiduría huera, pues muchas máximas contenidas en el libro El espíritu sij, firmado por Ripaldi, son creaciones del propio Escribano, redactadas con total desparpajo.

El Buscón es la autobiografía de un pícaro que no da consejos y que nunca se arrepiente de sus aventuras, a diferencia del Guzmán narrador, razones que han llevado a la crítica a considerar la creación de Quevedo como una parodia del Guzmán de Alfarache (Altenberg 2008, 358). De la misma manera que Quevedo se distancia de la fórmula de Alemán, Benítez Reyes en El azar y viceversa visita a la novela picaresca, y con humor ácido y nulas enseñanzas se contrapone a la finalidad moralizante exhibida en Alfarache, como sostiene Roncero sobre esta última obra $(2010,113)$. Incluso, con gran irreverencia, Escribano designa a su prosa como «escolástica», en abierta contraposición al discurso devoto de Guzmán:

Un dios es siempre un ente conflictivo: algo que vive en la insania de su omnipotencia $[\ldots]$ y de su clarividencia tenebrosa. Si me permite una divagación más o menos escolástica, le diré que, en el mejor de los casos, un dios sólo puede vivir horrorizado de su condición de dios, $[\ldots]$ de ser dueño y responsable tanto de lo puro como de la podredumbre (Benítez 2016, 377-378).

También la prosa de Escribano es burlesca al asociar el LSD con libros sacros:

Cayó por allí un holandés que se había traído de su tierra una Biblia empapada en ácido, de modo que podías comerte un fragmento de un versículo del Eclesiastés y volar a las regiones superiores de la mente, ensalivar dos letras del Génesis y trasladarte a un edén de colores puros, ponerte en la lengua una brizna $[\ldots]$ del

\footnotetext{
8 Esta visión se sostiene en Boto Bravo 2017, 99.
} 
Evangelio según San Lucas y propulsarte a la cumbre ingrávida de las sinestesias (ibíd., 119).

Asimismo, la novela de Benítez Reyes se deslinda de la novela canónica picaresca al incluir en su configuración descripciones de encuentros sexuales, como los experimentados por el protagonista con Mabel o con Geva; otras situaciones lúbricas se desenvuelven en planos desopilantes y grotescos, como las vividas por Escribano con la gitanilla Macarena o con las místicas del Retiro Karta Purukh. Por algo, el realismo irónico es parte fundamental «de la construcción del discurso humorístico literario de fin de siglo, no solo porque responde a su propia esencia lúdica, sino porque representa también la episteme posmoderna» (Boto 2017, 93).

La intertextualidad es una táctica que también los estudiosos han detectado en la novela posmoderna, pues son constantes las presencias efectivas de un texto en otro; como hemos demostrado en los dos primeros apartados, las alusiones, tanto a nivel enunciativo como diegético, ocurren entre El azar y viceversa y la novela picaresca. Remarcamos la intertextualidad con Lazarillo, sobre todo en la secuencia cuando Escribano es guía de un intelectual ciego y fantoche, que viaja a Alcalá para dictar una conferencia. El despertar al mundo, el hambre y la socarronería sobre el conocimiento campean en ambos pasajes, tanto en el de la novelita anónima como en la de Benítez. Además, el Tesoro de la lengua castellana o española es otra alusión, porque es la obra que dota de un vocabulario culto al relator y de la que extrae las palabras citadas en el epígrafe de la novela, ejes temáticos que arreglan su historia: «Amores, Azar, Confusión, Fortuna, Mundo».

El hibridismo genérico no es una constante en la estructura de El azar y viceversa; sin embargo, dejamos constancia del recurso que aparece en el «Segundo tramo», bajo el perfil de novela de campus9. Algunas páginas de este segmento -al que adjudicamos el subcapítulo «Días para el saber y noches de promisión»- se centralizan en la Facultad de Filosofía y Letras de la Universidad de Cádiz, condición para entroncar con el subgénero narrativo anotado. En estos fragmentos Escribano narra su experiencia de falso estudiante: las secuencias versan sobre las clases, el temor a que sus compañeros descubran su impostura, las actitudes soberbias de los profesores y la triquiñuela ideada por los alumnos de latín para superar un examen, argucia propia de la picaresca en el espacio estudiantil. Pero la aventura universitaria concluye cuando el Fiti colapsa y el «Rányer» ya no encuentra razón a su permanencia en la facultad, decisión que no le causa ningún pesar: su simulación como estudiante

9 En las novelas de campus los protagonistas, las temáticas y los espacios están ligados a la vida dentro de la universidad (profesores, decanos, estudiantes); por tanto, la contextualización y los entornos universitarios condicionan sus formas y contenidos narrativos (Gil-Albarellos 2017, 197). 
ha concluido y la vida en el aula lo ha desilusionado. En la órbita de la truhanería lo único en claro es la lucha por la subsistencia.

Otra cuestión que nos interesa es la «metaficción historiográfica», sintagma que Hutcheon aplica a cierta novela de la posmodernidad; a su entender, tres caracterizaciones la singularizan: es a un tiempo autorreferencial, por referirse a su propio contenido y al modo de su escritura, como ya explicamos; es referencial, por atender a cuestiones históricas (personajes y hechos); por último, es paródica al implantar y subvertir -mediante la ironía- componentes recogidos del pasado (Barbancho 2011, 98-99).

Rey y otros investigadores opinan que los materiales que contiene el Lazarillo proceden, en una buena parte, de fuentes folklóricas y de la realidad española de su momento histórico (1989a, 14). En esta línea, Valbuena Prat considera que en Alfarache se «abarca toda la pendiente de una sociedad corrompida, de toda una patria y un estado en señales de descomposición y decadencia» (1960, 120-121), como lo fue el final del reinado de Felipe II. Fiel al canon picaresco, Benítez Reyes obliga a su personaje a mirarse más allá de sí mismo para atender a la memoria colectiva: la guerra civil, el franquismo, la transición, la democracia, la intentona golpista del 23F.

La continuidad de El azar y viceversa radica en su trasfondo histórico, al igual que en las fabulaciones picarescas; la discontinuidad se pone de relieve al incluir reflexiones y opiniones del propio personaje, en muchas ocasiones sardónicas, sobre ese pasado histórico visto desde el presente. En esta tesitura, relacionamos El azar y viceversa con las nombradas «metaficciones historiográficas» por vincular «la reflexividad y la autoconciencia a un replanteamiento de las formas y contenidos del pasado» (Orejas 2003, 107-108). La irracionalidad de los bandos enfrentados en la guerra civil planean por la adolescencia del héroe: Fantomas se encarga de actualizar la violencia gracias a la casa que adquiere: un recinto inhóspito que fue cuartel falangista donde se torturó y asesinó durante la guerra; Antonio presiente un aura tenebrosa que envenena las vidas de sus nuevos moradores, por lo que denomina al sitio -sin ingenuidad y con sorna- como «la casa de los espectros» (Benítez 2016, 63). Por tal motivo, no es casual que Franco y sus colaboradores estuvieran empeñados todo el tiempo en propiciar la recordación de la guerra entre buena parte de la sociedad española, para que nadie deje de experimentar espontáneamente ese recuerdo día con día (Tusell 1996, 148). Otra anécdota de la trama recae sobre un cliente de Fantomas que fue fascista y saqueador, pero con la transición se volvió demócrata, como tantos españoles. Cobra significación el señalamiento de Eco sobre la literatura posmoderna que se aproxima al pasado para «volver a visitarlo; con ironía, sin ingenuidad» $(1985,74)$.

Al desmenuzar los rasgos del posmodernismo, Ihab Hassan expresa que «la historia es un palimpsesto» (Holloway 1999, 43). La imagen del manuscrito con huellas de una escritura anterior nos parece pertinente para recalcar la historicidad en la novela de Benítez Reyes: la guerra civil y los odios que no 
acaban de irse en el tardofranquismo son percibidos por el camarero Escribano en el Ruleta (de nuevo el irónico destino), un bar de viejos que no olvidan a los familiares asesinados. En consecuencia, «las miradas esquivas, las alusiones malintencionadas o el ostensible no mirarse» (Benítez 2016, 88) de los parroquianos, seres que combatieron en la guerra y que prefieren el silencio a las palabras. A cuarenta años del fin del conflicto, Escribano testimonia la perduración en la sociedad civil de un hecho luctuoso y traumático que ha estado presente como memoria histórica y al que no es tan fácil pasar página (Urioste 2009, 203). Una vez más, la prosa de Benítez encuadra con cruel ironía a los que tuvieron que ver con una guerra absurda, como necias son sus vidas después del conflicto: «allí estaban, con su ropilla remendada y sucia, bebiendo un vino malo, en sus eternos retornos a lo eternamente idéntico, que suele ser la malandanza más común en nuestra especie» (Benítez 2016, 88). La prosa de Escribano dialoga con la aseveración de Marcos de Obregón: la memoria es un «verdugo de los hombres desdichados, porque siempre les está representando los malos sucesos, los agravios pasados, las desdichas presentes y las sospechas de lo venidero y la desconfianza que tienen en todas las cosas» (Espinel 1973, 194-195).

En El azar y viceversa el pasado es sometido a revisión, más que por afanes nostálgicos, para desenmascararlo; en esta línea señala Hutcheon que «la postmodernidad es fundamentalmente irónica y así su relación con el pasado [es] una parodia de la nostalgia» (Barbancho 2011, 125). En un primer periodo vacacional, el «Rányer» viaja de Cádiz a Rota; allí visita ese espacio tan significativo: el Hades. Allí le sobreviene la experiencia reveladora de lo dejado atrás $\mathrm{y}$, en la democracia, diagnostica la impostura de los asistentes al bar: farsantes de la revolución y la lucha, de la cultura, hablantes de todo que se la pasaban «soñando siempre a lo grande. Pobres diablos [...] que intentaban elevarse un poco del suelo [...] anclados de por vida a un vacío repleto de palabras vacías y sin aplicación posible a ningún parámetro de realidad» (Benítez 2016, 196).

La realidad histórica parodiada en la novela es personificada por Romero. Se trata de un comerciante que, por la naciente democracia, se convierte en diputado autonómico; Romero es modelo del político rastrero y soez, del golfante y corrupto picarismo político que no fue privativo del franquismo, sino que siguió enquistado en la nueva etapa histórica; como recalca el mismo funcionario, «no había político que no enchufara en la administración pública al menos a media docena de familiares y allegados» (ibíd., 425). La política se volvió una profesión bastante lucrativa, por lo que muchos aficionados y cínicos se apoderaron de ella en el primer periodo de la transición, sujetos «que no han respirado otro aire ni estudiado otra carrera que la del medro político» (Muñoz 2013, 36-37). El diputado simboliza la deformación de la élite gobernante, pues «la parodia y la caricatura [...] consiguen crear un efecto de falsedad que enmascaran, pero no la ocultan, la crítica severa del modelo parodiado» 
(Boto 2017, 246). La autoironía de Escribano - emparentado con Pablos y Alfarache- es que él participa de parrandas y empleos fingidos, a cargo del erario, que provee el parlamentario.

La prosa picaril de Benítez Reyes dialoga con innegables señas de identidad de la posmodernidad; una de ellas es la destemporalización. Navajas la explica en función del individuo al que solo inquieta su supervivencia momentánea; una conducta que le produce una conciencia débil del tiempo histórico externo al yo, una escasa fijación de las circunstancias históricas, siempre y cuando graviten en torno a su percepción personal $(1996,27)$. Esto implica que el entramado histórico enzarzado en El azar y viceversa se refiera en función de las vivencias alrededor del sujeto ficcional, reflejo fiel de lo que explica Navajas sobre los principios que fundamentan la perspectiva del narrador posmoderno y que determinan lo historificado (ibíd., 29). Escribano radiografía la temporalidad generacional de los jóvenes de los setenta y ochenta -el tardofranquismo y la transición- que vieron sus vidas atravesadas por experiencias inéditas, muchas de ellas creadas por el consumismo y la moda: la revolución sexual, el rock, las drogas, la pornografía, la vestimenta psicodélica o hippie; cunde también la admiración por religiones orientales y la identificación con organizaciones violentas que nacieron en la época (GRAPO y ETA), al igual que con cuadros anarquistas o de izquierdas, como la Unión de Juventudes Maoístas. A Escribano, como a su generación, le queda un tanto distante el conflicto bélico, aunque sus consecuencias aún escuecen el ambiente social, pese a la desaparición física del Caudillo. Mas el peso de la historia poca mella produce en la conciencia anestesiada de sus coetáneos enganchados al alcohol y al hachís, vividores que se creen jóvenes para la eternidad, anclados en el tramo en el que se da por hecho «que la vida estará siempre ahí delante, nunca en la retaguardia» (Benítez 2016, 329). Esta última impresión se relaciona con la «sensación de presente perpetuo y sin profundidad» del sujeto posmoderno, idea sostenida por Jameson al explicar el «debilitamiento de la historicidad»y la ausencia de todo referente histórico (Barbancho 2011, 80-81).

La destemporalización de Escribano se recalca por ciertos hechos históricos que alude solo porque se entrecruzan con su vida etílica: «A los dos meses de morir Franco - suceso celebrado en el Hades con una ronda de cerveza a cuenta de la casa y con brindis más o menos furtivos- cumplí los dieciocho» (Benítez 2016, 90); o cuando una madrugada de borrachera se sorprende al encontrar al Tunecino y a sus empleados junto al radio, siguiendo el «golpe de Estado de los fascistas» (ibíd., 402), la intentona golpista del 23F. La sublevación que puso en vilo a la nación la hace rodar en torno de su vida: «la salvación del país no evitó el cataclismo de nuestro micromundo» (ibíd., 403), en alusión a la ruina de su primer matrimonio. La violencia política, la represión parapolicial y la intransigencia frente a la democracia parlamentaria y el Estado liberal (Rodríguez 1991, 275-277) son citadas solo porque Escribano es humillado, junto a su colega Bakunin, por una milicia falangista de Fuerza 
Nueva. La experiencia exterior consigue penetrarlo al grado de apuntar que «en la memoria hay fardos inamovibles» (Benítez 2016, 159).

Una de las aristas de la posmodernidad es el desencanto de las utopías, «la incredulidad frente a las fábulas maestras [o] master narratives» de la sociedad occidental, término utilizado por Foucault y Lyotard para referirse a «los valores ideológicos del poder que circula en ciertas creencias» (Holloway 1999, 38). El personaje que encarna este papel en la novela es Cupido López, joven anarquista seguidor de Bakunin, que sueña con un alzamiento popular y al que no importa exponer su integridad física; su lucha ideológica se refleja en los panfletos que imprime y reparte entre los del Hades, y en fundar La Comuna Bakunin, proyecto que acabó en fracaso al descreer sus habitantes en una auténtica vida comunitaria, al igual que la sociedad posmoderna que perdió la fe en «la evolución social hacia un estado más utópico» (ibíd., 38). De vuelta a Rota, Escribano comprueba que su amigo ha sido un anarquista de farsa, sin su oratoria incendiaria, como «si le hubieran [...] borrado de la corteza cerebral sus ideales antiguos» (Benítez 2016, 462), y arrastrado por la «dialéctica histórica» (ibíd., 481) para convertirse en exitoso dueño del videoclub La Comuna, subvencionado por su padre. La irónica situación del revolucionario quimérico encaja en la señalada por Jameson y Baudrillard: «el triunfo de lo superficial y lo apócrifo [y] del simulacrum que impera en la época» (Holloway 1999, 46), y se parangona a la reflexión de Lozano sobre el sujeto posmoderno, al que se le han difuminado las certezas y los radicalismos para dar paso a la tolerancia «que, para muchos, no es más que indiferencia y neoconservadurismo» $(2006,223)$, una vida, como la del falso Bakunin, que ha migrado hacia el individualismo egoísta y el consumismo rampante de la clase media.

Al analizar algunas novelas publicadas en el posfranquismo, Holloway resalta también otra de las cualidades posmodernas: la crisis del individuo envuelto por la vida azarosa, arbitraria, inestable y, en ocasiones, absurda (1999, 124). A conclusiones parecidas llega Vidal al resaltar que esta es una época «que abunda en incertidumbres [por lo que] la vida cotidiana funciona según el régimen de la sorpresa y la aventura [y donde lo real se aprehende] ahora bajo los efectos de lo aleatorio y lo contradictorio», que se ve reflejado en la creación artística $(1990,11)$. En muchas novelas contemporáneas «nos enfrentamos a personajes que habitan en un mundo a la deriva, sin planes, sin respuestas, rodeados por la nada» (ibíd., 22). Estas cualidades se vuelcan en la vida del héroe de El azar y viceversa, quien se autodefine como «un buscavidas que tenía en el bolsillo casi todas las papeletas de la tómbola de la desventura, con el riesgo de que me tocase el premio estelar y acabase en el Penal del Puerto de Santa María» (Benítez 2016, 264).

Una figura común - estudiada por Barbancho- en narraciones publicadas a partir de 1980 es la del individuo errabundo y desvinculado de su espacio, individuo que ha extraviado su «mundo» y no busca ya nada o busca en vano un nuevo «lugar en el mundo» $(2011,133)$. En este sentido, El azar y vicever- 
$s a$ es una novela que desarrolla el aislamiento y la desestabilización del ser como eje temático. Desde los trece años Antoñito no pertenece a un hogar: es huérfano de padre y cohabita con una madre que persigue al hombre ideal. Su orfandad existencial se recrudece con Fantomas, quien los traslada al centro de Rota, a una casona mal oliente, plagada de ratas, y le destina a él la peor habitación. No es extraño que lo acometa un espíritu de desafío contra el poder de Fantomas, y lo invada el desarraigo; no es casual que a la primera oportunidad huya de esa casa, espacio de control y vejaciones, donde nunca fue propenso a las manifestaciones de afecto, ni hacia su madre ni hacia los otros, por haberse «criado entre gente a la que jamás [vio] tocarse entre sí» (Benítez 2016, 180); las experiencias de Escribano revelan la incomunicación del sujeto escindido, que es transformado en protagonista itinerante, como otros personajes contemporáneos (Lozano 2006, 222).

La desterritorialidad de Escribano hacia su terruño se amplía hacia otras ciudades andaluzas. Un viaje de Cádiz a su pueblo natal le demuestra la ruptura: «... aquel era mi sitio y no era en absoluto mi sitio. Un vínculo tal vez irrompible, aunque misteriosamente roto» (Benítez 2016, 267). En una visita posterior a Rota se siente forastero, un ser sin ligaduras con la tierra nutricia: «Cuando cogí el autobús de regreso [a Sevilla] intuí que tardaría mucho en volver a mi lugar de origen [...] porque ese origen estaba ya muy diluido en su propia irrealidad» (ibíd., 362). En la novela posmoderna la representación del mundo es un problema ontológico, la realidad se desvanece, se invade de lo inestable y se convierte en una imagen, en una pérdida en la conciencia (Lozano 2006, 222). Para Escribano Rota es un lugar ajeno y sin querencia, que ya no asocia como suyo; él es un desterrado de ese espacio que arruina, como considera Barbancho, «el sentimiento de hogar» $(2011,118)$. La misma sensación de distanciamiento le sobreviene con Cádiz; después del desplome del Tunecino viaja desde Sevilla para saber del Palacio del Moro y comprobar «que nada me unía a aquella ciudad» (Benítez 2016, 410). Tampoco Sevilla es asidero. Vuelto otra vez al estado de paria no sabe hacia dónde enfilar sus pasos: «Dónde podía estar mi lugar en el mundo era algo que no podíamos saber ni el mundo ni yo» (ibíd., 426). Admite que su absurda travesía es un «peregrinaje hacia ninguna parte» (ibíd., 428), como ha sido toda su existencia, invadida de la sensación de sentirse un intruso, no solo en la vida universitaria, sino en la vida.

El azar «que tiene [la afición] a vivir perpetuamente como en insomnio» (ibíd., 427) devuelve a Escribano con la vida rota a Rota, inicio y fin del periplo picaresco. Rota da un giro a su existir y contradice a la reflexión última de don Pablos cuando esgrime que nunca mejora de estado quien muda solo de paraje. En este microcosmos Toni se comprende y es comprendido a un tiempo por los demás. Cesa su estado errabundo, y su retorno es un cruce con ese «mundo» que creía perdido y que, al recuperarlo, pone fin a su estado picaril; encuentra a la mujer amada, goza de una situación estable y -él 
que nunca la tuvo- funda una familia. Mas el destino malogra la vida y recuerda que el ser posmoderno es un ser fragmentado inmerso en el vórtice de la inestabilidad ontológica: la vida personal poseedora de continuidad, constancia, cohesión y seguridad en el sujeto modernista, se ha esfumado (Lozano 2007, 164).

En atención a que en algunos finales de las novelas picarescas el bribón anuncia más aventuras en otro volumen, o bien, advierte que ha llegado al desenlace de su relato pero no de su vida, Souiller apunta que esta narración «nunca termina: es un libro abierto para preservar la ficción de la autobiografía» $(1985,86)$. La tradición del final incierto en el género picaresco es alterada -posmodernamente- por Benítez Reyes; la culminación de El azar y viceversa revela que el fabulador escribe porque está al borde de la muerte, única certeza que le queda: «yo no voy ya detrás de nadie, sino a ser nadie. No voy detrás de nada, sino a la nada. Y quien me mira desde el espejo ya no sabe mentirme» (Benítez 2016, 502); por tanto, la obra que leemos es un libro finiquitado que fue retirado de la notaría donde la dejó depositada su autor; estamos ante una novela cerrada que no acepta ningún agregado más, ni promesas de segundas partes.

Holloway reflexiona que en ciertas novelas posmodernistas la vida se representa como un drama autoconsciente, como una sucesión de experiencias fortuitas e ineludibles; este planteamiento lo vemos relumbrar también en $\mathrm{El}$ azar y viceversa y nos escora a concluir -seguimos con el crítico- que la memoria, la conciencia, la experiencia histórica, la imaginación y la fantasía son componentes que fundan toda existencia, pero a la vez revelan la inestabilidad de la vida humana $(1999,121)$. Prueba de esto es la vida pícara y azarosa a la que fue arrojado Antonio Escribano.

\section{FUENTES}

Alemán, Mateo. 1971. Guzmán de Alfarache. Introducción de Amancio Bolaño e Isla. México: Editorial Porrúa.

Benítez Reyes, Felipe. 2016. El azar y viceversa. Barcelona: Destino.

Espinel, Vicente. 1973. Vida de Marcos de Obregón. Prólogo de Juan Pérez de Guzmán. México: Editorial Porrúa.

La vida de Lazarillo de Tormes. 1989. Edición de Antonio Rey Hazas. Madrid: Castalia.

La Vida y Hechos de Estebanillo González. 1971. Prólogo de Juana de Ontañón. México: Editorial Porrúa.

Luna, Juan de. 2014. Segunda parte del Lazarillo de Tormes. Ed. Alfredo Rodríguez LópezVázquez. Madrid: Cátedra.

Quevedo, Francisco de. 1998. El Buscón. Editado por Pablo Jauralde Pou. Madrid: Alianza. 


\section{BiBLIOGRAFÍA CITADA}

Altenberg, Tilmann. 2008. «Francisco de Quevedo, Historia de la vida del Buscón». En La novela picaresca. Concepto genérico y evolución del género (siglos XVI y XVII), ed. Klaus Meyer-Minnemann y Sabine Schlickers, 353-390. Frankfurt am Main: Vervuert.

Aguiar e Silva, Vítor Manuel. 1972. Teoría de la Literatura. Trad. de Valentín García Yebra. Madrid: Gredos.

Barbancho Galdós, Iñigo. 2011. Mundos perdidos: una aproximación tematológica a la novela postmoderna. Madrid: CSIC.

Bonilla, Juan. 2016. «Felipe Benítez Reyes. La construcción de una conciencia». Mercurio 181: $16-17$.

Boto Bravo, Miguel Ángel. 2017. Humor y posmodernidad: el humorismo en la narrativa de Eduardo Mendoza Garriga. Tesis doctoral. UNED.

Bubnova, Tatiana. 2006. «El ambiguo discurso de Guzmán de Alfarache». Acta Poética 2 (1-2). http://doi.org/10.19130/iifl.ap.1980.1-2.686

Cavillac, Michel. 2001. «El diálogo del narrador con el narratario en el Guzmán de Alfarache de Mateo Alemán». Criticón 81-82: 317-330.

Eco, Umberto. 1985. Apostillas a El nombre de la rosa. Trad. de Ricardo Pochtar. Barcelona: Editorial Lumen.

Gil-Albarellos, Susana. 2017. «La novela de campus en España 2000-2015». Cuadernos de Investigación Filológica 43: 191-207. http://doi.org/10.18172/cif.2987

Guillén, Claudio. 1983. «Constitución de un género: la novela picaresca». En Historia y crítica de la literatura española, III. Siglos de Oro: Barroco, coord. Bruce W. Wardropper, 468-471. Barcelona: Crítica.

Holloway, Vance R. 1999. El posmodernismo y otras tendencias de la novela española (1967-1995). Madrid: Editorial Fundamentos.

Laporte, Sarah. 2011. Replanteamiento de la poética de la novela picaresca a través del diálogo. Tesis doctoral. Universidad Autónoma de Madrid.

Lázaro Carreter, Fernando. 1983. «Lecturas del Buscón: entre el ingenio y la sátira social». En Historia y crítica de la literatura española, III. Siglos de Oro: Barroco, coord. Bruce W. Wardropper, 493-496. Barcelona: Crítica.

Lozano Mijares, M. ${ }^{a}$ del Pilar. 2006. «Andrés Ibáñez o la novela española posmoderna». Revista de Literatura LXVIII, 135: 221-246. https://doi.org/10.3989/revliteratura.2006. v68.i135.9

Lozano Mijares, M. ${ }^{a}$ del Pilar. 2007. La novela española posmoderna. Madrid: Arco/Libros.

Madigan, M. Kathleen. 2008. «¿Al otro lado del Posmodernismo? Marina Mayoral y el Neomodernismo». I Congreso Internacional de Literatura y Cultura Españolas Contemporáneas. La Plata: Universidad Nacional de la Plata https://www.aacademica. org/000-095/113.pdf

Moreno Báez, Enrique. 1983. «Guzmán de Alfarache: la narración como ejemplo». En Historia y crítica de la literatura española, III. Siglos de Oro: Barroco, coord. Bruce W. Wardropper, 480-483. Barcelona: Crítica.

Molho, Maurice. 1972. Introducción al pensamiento picaresco. Trad. de Augusto GálvezCañero y Pidal. Madrid: Anaya.

Montauban, Jannine. 2003. El ajuar de la vida picaresca: reproducción, genealogía y sexualidad en la novela picaresca española. Madrid: Visor.

Muñoz Molina, Antonio. 2013. Todo lo que era sólido. Barcelona: Seix Barral. 
Navajas, Gonzalo. 1996. Más allá de la posmodernidad. Estética de la nueva novela y cine españoles. Barcelona: EUB.

Oleza, Joan. 1993. «La disyuntiva estética de la posmodernidad y el realismo». Compás de Letras 3: 113-126. https://www.uv.es/entresiglos/oleza/pdfs/disyuntiva.PDF

Orejas, Francisco G. 2003. La metaficción en la novela española contemporánea. Madrid: Arco/Libros.

Rey Hazas, Antonio. 1989a. «Introducción». En La vida de Lazarillo de Tormes, 9-19. Madrid: Castalia.

Rey Hazas, Antonio. 1989b. «Orientaciones para el estudio del Lazarillo de Tormes». En La vida de Lazarillo de Tormes, 157-184. Madrid: Castalia.

Rey Hazas, Antonio. 1990. La novela picaresca. Madrid: Anaya.

Rico, Francisco. 1982. La novela picaresca y el punto de vista. Barcelona: Seix Barral.

Rico, Francisco. 1983. «Construcción y estilo del Guzmán de Alfarache». En Historia y crítica de la literatura española, III. Siglos de Oro: Barroco, coord. Bruce W. Wardropper, 486-490. Barcelona: Crítica.

Rodríguez Jiménez, José Luis. 1991. «Origen, desarrollo y disolución de Fuerza Nueva. Una aproximación al estudio de la extrema derecha española». Revista de Estudios Políticos 73: 261-287.

Roncero López, Victoriano. 2010. De bufones y pícaros: la risa en la novela picaresca. Madrid: Iberoamericana - Vervuert.

Sobejano, Gonzalo. 1964. «Sobre la novela picaresca contemporánea». Boletín Informativo de Derecho Político 31: 213-225.

Sobejano, Gonzalo. 1972. «Un perfil de la picaresca: el pícaro hablador». En Studia hispánica in honorem Rafael Lapesa, III, 467-485. Madrid: Gredos.

Souiller, Didier. 1985. La novela picaresca. Trad. de Beatriz Pillado-Salas. México: Fondo de Cultura Económica.

Tusell, Javier. 1996. La dictadura de Franco. Barcelona: Altaya.

Urioste Azcorra, Carmen de. 2009. Novela y sociedad en la España contemporánea (19942009). Madrid: Editorial Fundamentos.

Valbuena Prat, Ángel. 1960. Historia de la literatura española II. Barcelona: Editorial Gustavo Gili.

Vidal, M. ${ }^{a}$ Carmen África. 1990. Hacia una patafisica de la esperanza. Reflexiones sobre la novela posmoderna. Alicante: Universidad de Alicante.

Zamora Vicente, Alonso. 1962. Qué es la novela picaresca. Buenos Aires: Columba. http://www.cervantesvirtual.com/nd/ark:/59851/bmccj8cl

Zea Álvarez, Francisco. 2016. El motivo humorístico del viaje en la novela picaresca espanola e inglesa. Valladolid: Universidad de Valladolid.

Fecha de recepción: 23 de enero de 2019.

Fecha de aceptación: 25 de julio de 2019. 